\title{
YEMENI CIVIL WAR: CAUSES, CONSEQUENCES AND PROSPECTS
}

\author{
Niaz Ahmed \\ PhD Scholar, Centre for West Asian Studies \\ Jamia Millia Islamia, New Delhi, India \\ niazahmed487@gmail.com
}

\begin{abstract}
Yemeni conflict reflects the failure of the Yemeni government to address the common needs to its citizen, the uprising of politically marginalized Houthis and the corrupt state, which bring the country into civil war. This article is an attempt to know the causes, consequences, and the role of foreign powers and also the entire situation of Yemeni civil war. Yemen is the poorest Arab country in the world. Due to the effect of the Arab Socialist Movement, Yemen's Imamate ruling system disintegrated in 1970 and the country divided into two nations, North Yemen and South Yemen. Again in 1990 under the leadership of Ali Abdullah Saleh, both have been united into one nation. The corrupt rule of government, the unhealthy treatment of Houthi minority and the internal conflict made the country more unstable. Political transition happed in 2011 for the stabilization of the country, but it fails to bring peace and finally in 2015 Yemen faces a devastating civil war. Different attempts have been taken by the international community for normalizing the conflict, but all fail to bring peace. The country is suffering the worst humanitarian crisis. Saudi Arabia and Iran is the main player in the conflict. This qualitative study will try to highlight the different scenario of Yemen and also provide an overview of the civil conflict.

Keywords: Yemen, Houthis, Civil War, Humanitarian Crisis
\end{abstract}

\section{INTRODUCTION}

Since the emergence of Houthi insurgency in 2004 and side by side the rise of the Arab Spring, Yemen face great trouble in maintaining governance, which ultimately brings the civil war in 2015. Yemeni society is very multidimensional and there is also a sectarian dimension which played a major role in the conflict (Dresch 2000). Historically speaking, the country has experienced different uprising in different course of time since 1962 and also in 2004 and finally the devastating civil war in 2015, which is still going on. For the stabilization of Yemeni socio-political situation, a major political transition held in 2011, which replaced Yemeni President Ali Abdullah Saleh by his Vice-President Abde Rabbo Mansour Hadi (Lackner 2019). Despite the transition, the government was not able to control the internal conflicts and finally in 2015, the Hadi government fall down, while Houthi insurgent occupied Sana'a the Capital of Yemen. The entire trajectory of Yemeni 
conflict is very multidimensional because the division of Yemeni military, the SaudiIranian rivalry and the role of foreign powers such also made the situation more complex. During the political transition, Saleh wanted to bring his son as the military commander of Yemen, but Ahmar the Military commander not wanted to lose his position. That's why the entire military section of Yemen was divided into two particular groups, the Ahmar loyalist and Saleh's loyalist (Hill 2017). Then the Houthi took advantage and has started capturing the areas of North Yemen because the military was so weak. Side by side AI-Qaeda in the Arabian Peninsula and ISIS has taken advantage of the conflict and also spreading in Yemen since 2011, especially the areas of South Yemen (Phillips 2017).

The discovery of oil in the border regions of both North and South Yemen provided both parties with a financial incentive to strengthen their relations and finally on April 1990, under the leadership of Ali Abdullah Saleh both state signed a unity agreement to merge the both country into a new single nation, the Republic of Yemen (Fierstein 2019). Following that time Saleh has given emphasis only the Northern Yemeni people and his policy towards the southern people were not satisfactory, and the southern people upraised at different times. Another important thing was that the Zaydi Shia group of North Yemen which is known as Houthi lost their Imamate ruling system in North Yemen in 1970 due to Arab Nationalist Movement, and they were not happy with the Saleh rule, because they had not been treated properly by Saleh government (Day 2012). Houthis are a marginalized section in Yemeni politics, not getting proper help from the government and also feeling the fear of 'Sunnization' in their Zaydi heartland, that's why they stated revolution in Yemen under the backing of Iran. Data shows that Iran is providing arms and training to Houthis. According to different data, Houthis rose up against the Saleh's government in six times in between 2004 to 2010. For the normalization of the Yemeni situation, a 'National Dialogue Conference' was organized by GCC initiatives on March 2013 to January 2014 for the drafting of a new constitution and federal state (Fierstein 2019). United Nations also appointed Ismail Ould Cheikh Ahmed as Special Envoy for Yemen on April 14, 2015. UN Security Council adopted Resolution 2216, which imposed the sanctions on 
individuals undermining the stability of Yemen and authorized an arms embargo against the Houthi-Saleh forces. But all initiatives fail to bring peace in Yemen. Saudi Arabia is continuously conducting different military actions in Yemen for bringing the Hadi regime and stabilizing the situation with the help of different major powers, such as 'Operation Decisive Storm' in 2015.

\section{LITERATUE REVIEW}

Numbers of work have been done in Yemeni civil war. Here the researcher will analyze some of the important works. 'Yemen Endures: Civil War, Saudi Adventurism and the Future of Arabia' (2017) is an important book which explores the entire background of Yemeni civil war. This work talks about the imamate ruling system, the unification of Yemen, the tribal conflicts, Saudi-Iranian rivalry, and also the humanitarian situation of the country. 'Yemen: Civil War and Regional Intervention' (2019), is a good work which provides the impact of civil war on common people's life and how Saudi-Iran rivalry makes the situation worse, and also different socio-political scenario of Yemen. This book will help to understand the overall situation of Yemen. 'Yemen in Crisis: the Road to War' (2019), the book explores the present situation of Yemen, how the Houthi uprising brought the country politically unstable. The work also provides the information of Yemeni unification of 1990, the political transition of 2011, and relevant situations which made the country's situation conflictual.

'Yemen: the 60 Year War' (2019), is an important article which deals with the entire history of Yemeni civil war, its causes, its consequences, the role of neighbor countries. The article gives an idea about the role of the Yemeni army, Houthis, and foreign powers role. 'Yemen and the Politics of Permanent Crisis' (2017), the work gave an overview of the entire Yemeni civil conflict's background. It talks the Yemeni politics, the role of Yemeni political parties, the uprising of Houthis, the corrupt role of the Yemeni government and also the Saudi-Iranian rivalry which made the war more complex. 


\section{METHOD}

The study is descriptive in nature, based on analytical method. The sources of data collection are both primary and secondary sources on the subject. The primary data are collected from different records, reports, United Nations report. The secondary data are collected from review of available literature like books, articles published in various local, national and international journals; newspapers and magazines, and also from reliable and related websites and the websites of various independent organizations.

\section{DISCUSSION}

In this part the discussion will be on different causes which brought the civil war, the humanitarian situation of Yemen, the role of foreign powers and also will deal some prospects for the solution of the civil war.

\section{Causes of Yemeni Civil War}

There are numbers of causes which made the country unstable and finally, it enters into a civil war. The major causes of Yemeni civil war are mentioned below:

Firstly, Houthi insurgency is a major cause of Yemeni civil war. Houthis, a Zaydi Shia group who were marginalized in Yemeni politics and society since they lost their Imamate ruling system in 1970. They rose their voices different times, but the government manages them by different policies. Finally, they captured different territories of North Yemen and seized Sana'a the capital of Yemen and also dismissed the Hadi government.

Secondly, When Abdu Rabbu Mansour Hadi came to power as the President of Yemen under pressure from the International Monetary Fund, the Hadi government lifted fuel subsidies in July 2014 (Laub 2016). The Houthis, which were actively protested against the government they got the chance to mobilize people against the government and criticize the UN transition process and organized mass protests demanding lower fuel prices as well as a new government. Hadi's supporters and the 
Muslim Brotherhood-affiliated party, Al-Islah, organized a counter-rally. Houthis protest largely spread in North Yemen.

Thirdly, Armed Forces Split is another cause of Yemeni civil war. Military units loyal to Saleh the former President aligned themselves with the Houthis, contributing to their battlefield success (Ibid.,). Other militias mobilized against the Houthi-Saleh forces, aligning with elements of the military that remained loyal to the government of Hadi. Southern separatists ramped up their calls for secession. The entire military section of the country is divided.

Finally, Saudi Arabia's military intervention is also an important cause. The Houthis captured Aden, Hadi went into exile in Saudi Arabia, which launched a military campaign, primarily fought from the air, to roll back the Houthis and restore the Hadi government (Mitreski 2015). After launching military intervention the situation of Yemen become worst. Different groups are working for capturing power as Houthis in North Yemen, AI-Qaida and ISIS in South Yemen.

\section{Role of Foreign Powers}

The role of foreign power is very complex in the Yemeni conflict. The leader of the Sunni Muslim faith, Saudi Arabia and the leader of the Shia Muslim faith, Iran both are the major players of Yemen during the beginning time (Holzapfel 2013). Saudi Arabia and Iran both is the rival of each other. Both want to spread their political influence in the region. Iran's role is covered and it never declared that they are helping Houthis. The USA is also playing a critical role with its ally of Saudi Arabia. Saudi Arabia has remained supportive of the Hadi government and hence conducted military operations against the Houthis in Yemen. According to Al-Arabiya, "Saudi Arabia contributed over 100 warplanes and 150,000 soldiers as part of Operation Decisive Storm. Along with the members of the Gulf Cooperation Council (except Oman), Saudi Arabia led a series of airstrikes conducted against civilian infrastructure in Yemen, aimed at destroying Houthis strongholds. The Royal Saudi Air Force has been extensively involved in the taking down of Houthi air defenses." It has also destroyed numerous Houthis fighter 
planes, and hence secured most of the Yemeni airspace. According to different data, "On March 2017, the United States conducted over 40 airstrikes against Al-Qaida in the Arabian Peninsula (AQAP) inside Yemen, which US officials said were coordinated with the Hadi government" (Dunning 2018).

Oman is the only Gulf Monarchy which is not taking part in the Yemeni conflict. United Arab Emirate is also playing a role in Yemen. In the beginning time, UAE was with Saudi Arabia, but now its role is normal. Turkey, Pakistan, Australia and also the UN call for the ceasefire in Yemen. Still, Saudi Arabia is bombing in different Houthi dominant areas of North Yemen. In March 2019, the US Senate passed legislation to end the Saudi-led coalition war in Yemen, but it faced president veto and finally, the bill dismissed (Fierstein 2019).

\section{Humanitarian Situation}

Yemen is facing an unprecedented humanitarian crisis after the emergence of civil war. Yemen is the poorest Arab country in the world. The country has approximately 27.4 million people with chronic natural resource and food shortfalls (Sharp 2017). According to the World Food Program, "an estimated 7.3 million Yemenis need immediate food aid." According to UNICEF, "as many as 462,000 children suffer from severe acute malnutrition." According to the World Health Organization, "14.8 million people lack access to basic health care. There are over 2 million internally displaced in persons in Yemen. 17 million people are in crisis or emergency food situations." The UN refugee agency (UNHCR) estimates that more than 2.4 million Yemenis have fled their homes elsewhere in the country. In January 2017, UN estimates, "more than 10,000 people have been killed in the conflict, 4000 of them civilians. The majority of deaths have been caused by airstrikes led by Saudi Arabia." According to the United Nations Report of 2019, "Yemen's humanitarian crisis is the worst in the world, with close to 80 percent of Yemen's population of nearly 30 million needing some form of assistance. Two-thirds of the population is considered food insecure; one third is suffering from extreme levels of hunger; and estimates that 230 out of Yemen's 333 districts are at risk of famine and 
also notes that humanitarian assistance is increasingly becoming the only lifeline for millions of Yemenis." (UN Report 2019).

\section{Prospects for the Solution of Civil War}

United Nations and different foreign power has taken various attempt for the stabilization of Yemeni situation. But all effort fails to produce positive result. This study will provide some recommendation for the Yemeni situation-

- Houthis should withdraw from all Yemeni cities and restore the exiled president Abd Rabbo Mansour Hadi government temporarily, and hold an early election for new parliament and president.

- An international conference should be organized by GCC states under the banner of UN for the drafting of a new constitution, where all Yemeni political parties should send their representative, Houthi leader should be present and also representatives should be provided by neighboring powers such as Turkey, Pakistan. The new constitution should focus on special rights and facilities to minority (Houthis), and also provide them political reservation.

- GCC states should take lead for Yemen's recovery and provide financial aid.

- The World Bank (WB) and International Monetary Fund (IMF) should provide financial aid for recovery.

- United Nations should provide a special military force temporarily in Yemen for checkup the Yemeni situation, and after the new election, the forces should be withdrawn.

\section{CONCLUSION}

In the end, it can be concluded that the root of Yemeni civil war is the failure of Yemeni society to resolve the popular anger and address the frustration arising from economic disenfranchisement, political marginalized and the effects of an extractive, rentier and corrupt state. These systematic failures bring political upheavals and finally, the country 
entered into civil war. It is found that two Middle East power, the Sunni Saudi Arabia and Shia Iran are playing a major role in the civil conflict. The political transition of 2011 failed to meet a proper solution and Houthi forces captured Sana'a the capital of Yemen in 2014, and finally, the Hadi government fall down, which bring the civil war. It is seen the foreign power is also playing an important role for the solutions of the situation, such as GCC initiates NDC recommendations, UN also sent special envoy, but all initiatives failed because no conflict party is going to negotiate. Another important founding is that the entire military section of Yemen became weak due to internal political conflict. Militaries were used by Yemen for the protection of regime security rather than the protection of people. As a result of the civil war, thousands of peoples became refugees and lots of people fled to other countries for their security. At present, the situation was made more complex by divisions within the Saudi-led coalition. Saudi Arabia reportedly backs Mr. Hadi, who is based in Riyadh, while the United Arab Emirates is closely aligned with the separatists and there is no result coming. The USA is still providing arms support to Saudi led coalition and Saudi Arabia is continuously bombing in the in Yemen.

\section{REFERENCE}

Acemoglu, Daron and James Robinson. 2012. Why Nations Fail: The Origins of Power, Prosperity and Poverty. London: Crown Publishing Group.

Brandt, Marieke. 2017. Tribes and Politics in Yemen: A History of the Houthi Conflict. Oxford and New York: Oxford University Press.

Brehony, Noel. 2015. "The current situation in Yemen." The Norwegian Peace building Resource Centre.

Cordesman, Anthony H. 2015. "Yemen and Warfare in Failed States", Center for Strategic and International Studies.

Day, Stephen. 2012. Regionalism and Rebellion in Yemen: A Troubled National Union. Cambridge: Cambridge University Press. 
Dresch, Paul. 2000. A History of Modern Yemen. UK and New York: Cambridge University Press.

Fierstein, Gerald M. 2019. Yemen: The 60 Year War. USA: Middle East Institute.

Ghamari, Magdalena El. 2015. "Yemen- the Proxy War." Securitologia 2: 43-56.

Hill, Ginny. 2017. Yemen Endures: Civil War, Saudi Adventurism and the Future of Arabia. Oxford: Oxford University Press.

Huwaidin, Mohamed Bin. 2015. "The Security Dilemma in Saudi-Iranian Relations." Review of History and Political Science 3 (2): 69-79.

"Iran arming Houthis since 2009." Middle East Monitor: UN Report. 2017.

Jongberg, Kirsten. 2016. "The Conflict in Yemen: latest development." Directorate General for External Policies." European Parliament.

"Key facts about the war in Yemen." ALJAZEERA Report. 2016.

Lackner, Helen, 2019. Yemen in Crisis: Road to War. London and New York: Verso.

Lackner, Helen. 2014. Why Yemen Matters: A Society in Transition. London: Saqi Books.

Laub, Zachary. 2016. "Yemen in Crisis." Council on Foreign Relations, USA.

Lopour, Jacqueline. 2016. "Spotlight on Yemen's Forgotten War and Humanitarian Disaster." Centre for International Governance Innovation.

Makhmutov, Timur. 2017. "Yemen Crisis: Causes, Threats and Resolution Scenarios." Russian International Affairs Council.

McPherson, James H. 2011. The Civil War. New York: Mariner Books.

Mitreski, Aleksandar. 2015. "Civil war in Yemen: A Complex Conflict with Multiple Futures." Doha: Arab Center for Research and Policy Studies.

Nunlist, Christian. 2015. "War in Yemen: Revolution and Saudi Intervention." CSS Analyses in Security Policy 175 (2): 1-4.

Phillips, Sarah. 2017. Yemen and the Politics of Permanent Crisis. London and New York: Routledge.

Rab, Uzi. 2015. Yemen: Revolution, Civil War and Unification. London and New York: I.B. Tauris.

“The Forgotten War: The Ongoing Disaster in Yemen." The Soufan Center. 2018. 
Trofimov, Yaroslav. 2017. "Washington Turns Its Focus to Yemen, Pleasing Saudis." Wall Street Journal. (https://www.wsj.com/articles/washington-turns-attention-toyemen-pleasing-gulf-states-1486636201). Accessed July 25, 2019. 